\title{
PENGARUH KEMAMPUAN KOMUNIKASI MATEMATIS DAN KEMANDIRIAN BELAJAR TERHADAP PRESTASI BELAJAR MATEMATIKA
}

\author{
Nur Afiani \\ SDIT Fisabilillah, Kebagusan, Jakarta Selatan. \\ e-mail: fianurafiani30@gmail.com
}

\begin{abstract}
Abstrak: Pengaruh Kemampuan Komunikasi Matematis dan Kemandirian Belajar terhadap Prestasi Belajar Matematika. Tujuan dari penelitian ini adalah untuk mengetahui pengaruh kemampuan komunikasi matematis dan kemandirian belajar terhadap prestasi belajar matematika, mengetahui pengaruh kemampuan komunikasi matematis terhadap prestasi belajar matematika, dan mengetahui pengaruh kemandirian belajar terhadap prestasi belajar matematika Metode yang digunakan oleh peneliti dalam melakukan penelitian ini adalah metode survei. Populasi terjangkau dalam penelitian ini adalah seluruh siswa kelas VII MTs Daarussalaam Jakarta Selatan. Sampel dalam penelitian ini adalah sebanyak 41 siswa yang diambil dengan teknik random sampling. Instrumen untuk mengumpulkan data pada penelitian berupa tes uraian (essay) yang terdiri dari 11 butir soal untuk soal kemampuan komunikasi matematis dan angket terdiri dari 25 butir soal. Sedangkan prestasi belajar matematika bersumber dari dokumen sekolah berupa nilai Ujian Tengah Semester (UTS) kelas VII pada semester genap. Teknik analisis data yang digunakan melalui statistik deskriptif, koefisien korelasi ganda, dan analisis regresi. Disimpulkan terdapat pengaruh yang signifikan Kemampuan Komunikasi Matematis dan Kemandirian Belajar secara bersama-sama terhadap Prestasi Belajar Matematika. Terdapat pengaruh yang signifikan Kemampuan Komunikasi Matematis terhadap Prestasi Belajar Matematika dan terdapat pengaruh yang signifikan Kemandirian Belajar secara bersama-sama terhadap Prestasi Belajar Matematika.
\end{abstract}

Kata Kunci: Kemampuan Komunikasi Matematis, Kemandirian Belajar, Prestasi Belajar Matematika.

\begin{abstract}
: the impacts of mathematical communication ability and learning independence on mathematical learning achievement. This research is aimed to analyze the impacts of mathematical communication ability and learning independence on mathematical learning achievement. The method used in this research is a survey methode. Affordable population are all students 7 grade at MTS Darussalam Jakarta. Sample size is 41 respondents, taken by using simple random sampling. The instrument used is 11 essay test and 25 questionnaire on variables of mathematical communication ability and the result of even mid test on variable mathematical learning achievement. Analysis technique of the data are descriptive satitistic, double correlation coefisien and regression analysis. The research result show that, there are significant impacts of both mathematical communication ability and learning independence on mathematical learning achievement all together. There are significant impacts of mathematical communication ability on mathematical learning achievement There are significant impacts of learning independence on mathematical learning achievement.
\end{abstract}

Keywords: Mathematical Communication Ability, Learning Independence, Mathematical Learning Achievement. 


\section{PENDAHULUAN}

Pendidikan sebagai salah satu wahana pembentuk karakter bangsa, dimana pendidikan dipercaya sebagai wadah yang dapat membangun kecerdasan siswa serta dapat membangun kepribadian siswa ke arah yang lebih baik. Melalui pendidikan, diharapkan siswa dapat memiliki kemampuan berpikir logis, kritis, kreatif, produktif, dan dapat bekerjasama serta memiliki kemampuan Ilmu Pengetahuan dan Teknologi juga Seni serta Iman dan Taqwa yang tinggi. Saat ini kehidupan berbangsa dan bernegara memasuki era globalisasi dan pasar bebas, dimana setiap individu dihadapkan pada perubahan-perubahan yang tidak menentu. Salah satunya adalah perubahan yang terjadi pada sistem pendidikan. Sumber Daya Manusia (SDM) yang berkualitas dan unggul merupakan faktor penting dalam pembangunan pada era globalisasi saat ini. Untuk menghasilkan SDM yang berkualitas dan unggul diperlukan adanya peningkatan mutu, baik proses maupun hasil dalam pendidikan.

Menyadari akan hal tersebut, pemerintah telah melakukan berbagai upaya dalam mengatasi pendidikan di Negara Indonesia, diantaranya adalah dengan penyempurnaan kurikulum pendidikan, perbaikan kualitas dan meningkatkan kesejahteraan tenaga kependidikan, penyediaan media atau sarana pendidikan, perbaikan metode pengajaran, pelaksanaan Bantuan Operasional Sekolah (BOS), serta peningkatan kualitas lembaga pendidikan yang diselenggarakan oleh masyarakat maupun pemerintah. Dengan sistem pendidikan yang baik, diharapkan muncul generasi penerus bangsa yang berkualitas dan mampu menyesuaikan diri secara dinamis beradaptasi dalam hidup bermasyarakat, berbangsa, dan bernegara.
Inti kegiatan dalam pendidikan merupakan pembelajaran, dimana salah satu program pemerintah yaitu memusatkan mutu pendidikan pada peningkatan Kegiatan Belajar Mengajar (KBM) yang di dalamnya terdapat guru dan siswa sebagai unsur manusiawi. Dalam KBM, terjadi interaksi antara guru dengan siswa yang melibatkan berbagai kegiatan atau tindakan yang harus dilakukan. Guru berkewajiban merencanakan dan melaksanakan pembelajaran dengan sebaik mungkin, karena perencanaan dan pelaksanaan yang baik akan membawa hasil yang baik pula.

Guru mempunyai tugas untuk mendorong, membimbing, dan memberi fasilitas belajar bagi siswa untuk mencapai tujuan pembelajaran. Guru tidak terbatas sebagai penyampai ilmu pengetahuan, akan tetapi guru juga bertanggung jawab untuk membantu proses perkembangan kepribadian siswa. Interaksi belajar mengajar yang baik adalah guru sebagai pengajar tidak mendominasi kegiatan, tetapi membantu menciptakan kondisi yang kondusif serta memberikan motivasi dan bimbingan agar siswa dapat mengembangkan segenap potensi melalui kegiatan pembelajaran termasuk pada pelajaran matematika.

Keberhasilan siswa dalam belajar bergantung pada proses belajar mengajar. Untuk mewujudkan proses dan produk tersebut, kemampuan mendayagunakan metode atau cara mengajar sangat diperlukan untuk lebih menjamin swadaya dan swakarsa siswa yang sesuai dengan perkembangan Ilmu Pengetahuan dan Teknologi. Keberhasilan pembelajaran bukan hanya tanggung jawab lembaga pendidikan, melainkan tanggung jawab bersama, sinergi antara guru di kelas, orangtua di rumah, dan masyarakat di lingkungan tempat tinggal. 
Pendidikan matematika sebagai salah satu bidang dalam pendidikan, memegang peran penting dalam meningkatkan mutu pendidikan. Pembelajaran matematika tidak sematamata hanya menanamkan pengetahuan saja, akan tetapi dapat membentuk sikap positif, keterampilan cermat, dan kritis. Standar kompetensi dan kompetensi dasar matematika disusun sebagai landasan pembelajaran untuk mengembangkan kemampuan tersebut di atas. Selain itu, mempelajari matematika memungkinkan pula dapat mengembangkan spesifik kemampuan matematika dalam pemecahan masalah sehari-hari atau mengkomunikasikan ide atau gagasan dengan menggunakan simbol, tabel, dan diagram.

Tercapai atau tidaknya tujuan pembelajaran matematika dapat dilihat dari prestasi belajar matematika yang dicapai siswa setelah proses pembelajaran selesai. Besar kemungkinan prestasi belajar matematika dipengaruhi oleh kemampuan akademis siswa dan tinggi rendahnya atau efektif tidaknya proses pembelajaran. Seorang siswa diharapkan untuk lebih giat dalam belajar agar dapat mencapai nilai standar yang ditetapkan oleh pemerintah untuk melanjutkan pendidikan. Nilai minimal tertentu untuk mata pelajaran matematika yang ditentukan oleh pemerintah menunjukkan hasil prestasi belajar matematika siswa di sekolah.

Pembelajaran matematika perlu dirancang sedemikian, sehingga dapat menstimulasi siswa untuk mampu berkomunikasi dengan baik. Proses komunikasi yang baik ini diharapkan dapat menstimulasi siswa untuk mengembangkan berbagai ide matematika atau membangun pengetahuannya. Proses komunikasi akan terjadi apabila terjadi interaksi dalam pembelajaran. Komunikasi menjadi bagian yang erat dalam kehidupan sehari-hari. Komunikasi antar guru dan siswa maupun siswa dengan siswa sangat penting dalam proses belajar mengajar, sehingga diharapkan tujuan pembelajaran dapat tercapai. Komunikasi antara siswa dan guru sangat mempengaruhi prestasi belajar siswa khususnya dalam pelajaran matematika.

Kemampuan komunikasi matematis merupakan salah satu kemampuan dasar yang harus dimiliki siswa dan guru dalam KBM, terutama dalam pembelajaran matematika. Ketika siswa ditantang berpikir tentang matematika dan mengkomunikasikan hasil pikiran mereka secara lisan atau dalam bentuk tulisan, berarti mereka sedang belajar menjelaskan dan meyakinkan apa yang ada di dalam benak mereka. Melalui pembelajaran matematika, siswa diharapkan dapat mengkomunikasikan berbagai gagasan dengan simbol, tabel, diagram, atau media lain untuk memperjelas keadaan atau masalah.

Kemampuan komunikasi dalam matematika menolong guru memahami kemampuan siswa dalam menginterpretasikan berbagai bentuk pemahamannya tentang konsep dan proses matematika yang mereka pelajari. Dengan demikian, melalui komunikasi yang efektif diharapkan tujuan-tujuan pembelajaran dapat tercapai. Diharapkan guru dapat menumbuhkembangkan kemampuan komunikasi matematis siswa baik di dalam maupun di luar kelas, agar siswa dapat berkomunikasi secara cermat, tepat, sistematis, dan efisien dalam pembelajaran, terutama dalam pembelajaran matematika. Selain kemampuan komunikasi, agar memperoleh prestasi belajar matematika yang optimal, siswa harus mampu mandiri dalam belajar. 
Kemandirian belajar merupakan salah satu hal penting dalam belajar. Artinya, siswa perlu memiliki kesadaran, kemauan, dan motivasi dari dalam diri siswa untuk berbuat, bertindak, dan berpikir atas dasar kreatif dan penuh inisiatif, percaya diri, bertanggung jawab, dan bukan sematamata tekanan dari guru atau pihak lain. Dalam belajar dibutuhkan kemandirian, karena dengan adanya kemandirian dalam proses belajar diharapkan siswa tersebut mempunyai tanggungjawab dalam mengatur dan mendisiplinkan dirinya serta mengembangkan kemampuan belajar atas kemauan sendiri tanpa ada paksaan dari orang lain. Pembelajaran akan lebih efektif jika siswa melakukan kegiatan belajar atas kesadaran dan kemauannya sendiri, bukan dalam keadaan terpaksa atau tertekan.

Kemandirian merupakan perilaku individu yang mampu berinisiatif, mampu mengatasi hambatan atau masalah, mempunyai rasa percaya diri dan dapat melakukan sesuatu sendiri tanpa bantuan orang lain. Dibutuhkan kemandirian siswa dalam belajar, baik sendiri maupun bersama temantemannya untuk mengembangkan potensi yang ada di dalam siswa masing-masing. Siswa dikatakan telah mampu belajar secara mandiri apabila telah mampu melakukan tugas belajar tanpa ketergantungan dengan orang lain. Dengan kemandirian membuat siswa terlatih dan mempunyai kebiasaan melakukan tindakan yang baik serta dapat mengatur setiap tindakannya sehingga siswa mempunyai kedisiplinan dalam proses belajar.

\section{METODE}

Penelitian dilaksanakan di MTs Daarussalaam yang beralamat di Jln. Moh. Kahfi II No. 28 Kelurahan Srengseng Sawah, Kecamatan
Jagakarsa, Jakarta Selatan. Penelitian ini dilakukan pada siswa kelas VII semester genap tahun akademik 2015/2016 dengan jumlah siswa sebanyak 436 siswa, yang terbagi menjadi kelas VII sebanyak 162 siswa, kelas VIII sebanyak 148 siswa, dan kelas IX sebanyak 126 siswa. Penelitian ini dilaksanakan pada semester genap tahun akademik 2015/2016, yaitu pada bulan Maret sampai dengan bulan Juli 2016. Metode penelitian yang digunakan dalam penelitian ini adalah metode survai. Pada penelitian ini, desain penelitian yang digunakan adalah analisis korelasi regresi ganda. Desain penelitian pada penelitian ini digambarkan dengan paradigma penelitian sebagai berikut:

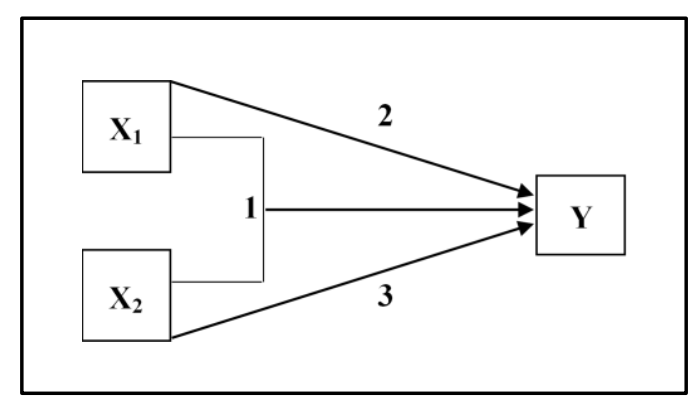

Gambar 1. Desain Penelitian

Keterangan:

$\mathrm{X}_{1}$ : Kemampuan Komunikasi Matematis

$\mathrm{X}_{2}$ : Kemandirian Belajar

$\mathrm{Y}$ : Prestasi Belajar Matematika

1 : Pengaruh Kemampuan Komunikasi Matematis dan Kemandirian Belajar Secara Bersama-sama terhadap Prestasi Belajar Matematika

2 : Pengaruh Kemampuan Komunikasi Matematis terhadap Prestasi Belajar Matematika

3 : Pengaruh Kemandirian Belajar terhadap Prestasi Belajar Matematika 
Populasi target dalam penelitian ini adalah seluruh siswa MTs Daarussalaam, Jakarta Selatan. Populasi terjangkau dalam penelitian ini adalah siswa kelas VII MTs Daarussalaam yang berjumlah 162 siswa. Adapun penelitian ini mengambil sampel sebanyak 41 siswa dari jumlah populasi terjangkau yang diteliti. Pengambilan sampel dalam penelitian ini dilaksanakan dengan cara mengundi (simple random sampling), sehingga memungkinkan setiap individu mempunyai kesempatan yang sama untuk diambil menjadi sampel. Teknik pengumpulan data yang digunakan berupa tes uraian (essay) dan angket. Berisi 15 butir soal uraian (essay) komunikasi matematis dan 30 butir pernyataan kemandirian belajar. Sedangkan untuk prestasi belajar matematika, pengumpulan data dilakukan dengan mengambil data dari dokumen sekolah berupa nilai UTS siswa kelas VII MTs Daarussalaam, Jakarta Selatan pada semester genap.

Indikator kemampuan komunikasi metamatis siswa merujuk pada Ramdhana, (2012: 47), yaitu kemampuan untuk berkomunikasi yang meliputi kegiatan penggunaan keahlian menulis, menyimak, menelaah, menginterpretasikan, dan mengevaluasi ide, simbol, istilah, serta informasi matematika yang diamati melalui proses mendengar, mempresentasi, dan diskusi.
Selain merujuk pada Ramdhana, (2012: 47), kemampuan komunikasi metamatis siswa juga merujuk pada pendapat Jazuli (2009: 215), yaitu kemampuan siswa dalam hal menjelaskan suatu algoritma dan cara unik untuk pemecahan masalah, kemampuan siswa mengkonstruksi dan menjelaskan sajian fenomena dunia nyata secara grafis, kata-kata atau kalimat, persamaan, tabel dan sajian secara fisik atau kemampuan siswa memberikan dugaan tentang gambar-gambar geometri. Dengan demikian, kemampuan komunikasi matematis siswa adalah skor tentang kemampuan siswa dalam mengekspresikan, menginterpretasikan, mengevaluasi ide-ide dan notasi matematika yang diukur melalui kemampuan menjelaskan ide dan situasi secara tulisan; menyatakan gambar atau diagram ke dalam ide-ide matematika; dan menyatakan situasi ke dalam model matematika. Skoring kemampuan komunikasi matematis diperoleh melalui pemberian 15 soal uraian yang diberikan kepada siswa. Untuk memperoleh skor tes kemampuan komunikasi matematis siswa, maka disusun pedoman penskoran Maryland Math Communication Rubric yang dimodifikasi dan dikeluarkan oleh Maryland State Departement of Education (Wahyuningrum, 2013: 5) seperti yang disajikan pada Tabel 1 .

\section{Tabel 1. Pedoman Penskoran Tes Kemampuan Komunikasi Matematis}

\begin{tabular}{cl}
\hline Skor & \multicolumn{1}{c}{ Kemampuan Komunikasi } \\
\hline 4 & $\begin{array}{l}\text { Penggunaan bahasa matematika (istilah, simbol, tanda, representasi) yang sangat efektif, } \\
\text { akurat, dan menyeluruh, untuk menggambarkan operasi, konsep, dan proses penyelesaian. } \\
\text { Penggunaan bahasa matematika (istilah, simbol, tanda, representasi) yang sebagian efektif, } \\
\text { akurat, dan menyeluruh untuk menggambarkan operasi, konsep dan proses penyelesaian. } \\
2\end{array}$ \\
$\begin{array}{l}\text { Penggunaan bahasa matematika (istilah, simbol, tanda dan / atau representasi) yang minimal } \\
\text { efektif dan akurat, untuk menggambarkan operasi, konsep, dan proses penyelesaian. }\end{array}$ \\
1 & Jawaban tidak benar, upaya yang dibuat tidak benar. \\
0 & Kosong, atau jawaban tidak cukup untuk mendapat skor.
\end{tabular}

Sumber: http://web.njit.edu/ ronkowit/teaching/rubrics 
Kemandirian belajar siswa pada pelajaran matematika adalah skor yang diperoleh dari hasil penilaian skala angket kemandirian belajar siswa sebanyak 30 butir pernyataan. Angket kemandirian belajar siswa berbentuk skala Likert dengan rentang angka 1 sampai 5 untuk pernyataan negatif dan angka 5 sampai 1 untuk pernyataan positif. Adapun indikator kemandirian belajar merujuk pada Sumarmo dalam Sugandi (2013: 149), yaitu: Inisiatif Belajar, Mendiagnosa Kebutuhan Belajar, Menetapkan Target/Tujuan Belajar, Memonitor, Mengatur, dan Mengontrol Belajar, Memandang Kesulitan sebagai Tantangan, Memanfaatkan dan Mencari Sumber yang Relevan, Memilih dan Menerapkan Strategi Belajar, Mengevaluasi Proses dan Hasil Belajar, serta Konsep Diri/Kemampuan Diri.

\section{HASIL DAN PEMBAHASAN}

\section{Hasil Penelitian}

Berdasarkan penelitian yang peneliti lakukan dapat diketahui data mengenai siswa di MTs. Daarussalaam tahun akademik 2015/2016 yang memiliki beberapa karakteristik, yaitu siswa yang diambil sebagai responden berada pada jangkauan umur 13-14 tahun untuk kelas VII. Siswa yang dijadikan sampel memiliki kondisi jasmani yang sehat. Secara fisik para siswa tumbuh dengan fisik yang normal dan psikis yang stabil. Sekitar $60 \%$ dari 41 responden merupakan anak-anak dengan jangkauan ekonomi menengah ke bawah dengan rata-rata prestasi kelas VII yang terdiri dari 4 rombongan kelas berada pada rentang nilai 30-50 berdasarkan data ulangan harian guru untuk materi himpunan. Dari aspek ranah kognitif, siswa di tempat penelitian memiliki karakteristik yang heterogen, dimana ada siswa yang sedang, baik, dan sangat baik berdasarkan kemampuan kognitifnya. Adapun dalam menggunakan bahasa sehari-hari, siswa di tempat penelitian menggunakan Bahasa Indonesia.

Secara pengujian statistik deskriptif, deskripsi data Prestasi Belajar Matematika (Y) diperoleh bahwa data prestasi belajar matematika memiliki nilai rata-rata $=38,10$; median $=38,55 ;$ modus $=40,30 ;$ varians $=$ 114,67 dan simpangan baku $=10,70$. Deskripsi Data Kemampuan Komunikasi Matematis $\left(\mathrm{X}_{1}\right)$ diperoleh bahwa data kemampuan komunikasi matematis dengan materi himpunan memiliki nilai rata-rata $=32,90$; median $=33,55 ;$ modus $=34,63$; varians $=53,811$ dan simpangan baku $=7,33$. Deskripsi Data Kemandirian Belajar $\left(\mathrm{X}_{2}\right)$ diperoleh bahwa data kemandirian belajar memiliki nilai ratarata $=44,45$; median $=45,17$; modus $=47,50 ;$ varians $=96,951$ dan simpangan baku $=9,84$.

Kemudian secara inferensial, harus melalui tahapan pengujian persyaratan analisis data untuk uji normalitas, uji linearitas, dan uji multikolinearitas. Uji normalitas data dilakukan untuk mengetahui apakah data yang akan dianalisis berdistribusi normal atau tidak. Untuk uji normalitas pada penelitian ini menggunakan uji chi-kuadrat dengan kriteria pengujian $\alpha$ $=0,05$ dan jumlah responden $\mathrm{n}=41$, maka nilai $\chi_{\text {tabel }}^{2}$ adalah 11,07 dengan ketentuan: "Jika $\chi_{\text {hitung }}^{2}<\chi_{\text {tabel }}^{2}$ maka data sampel berasal dari populasi yang berdistribusi normal, namun jika $\chi_{\text {hitung }}^{2}>\chi_{\text {tabel }}^{2}$ maka data sampel berasal dari populasi yang tidak berdistribusi normal". Berdasarkan perhitungan yang sudah dilakukan, berikut ini ringkasan hasil uji normalitas data untuk semua variabel penelitian. 
Tabel 2. Hasil Pengujian Normalitas Data

\begin{tabular}{clcccc}
\hline No & \multicolumn{1}{c}{ Perangkat Tes } & N & $\chi_{\text {hitung }}^{2}$ & $\chi_{\text {tabel }}^{2}$ & Simpulan \\
\hline 1 & Kemampuan Komunikasi Matematis & 41 & 3,45 & 11,07 & Normal \\
2 & Kemandirian Belajar & 41 & 4,40 & 11,07 & Normal \\
3 & Prestasi Belajar Matematika & 41 & 2,02 & 11,07 & Normal \\
\hline
\end{tabular}

Setelah uji normalitas, dilanjutkan dengan uji linearitas. Pengujian persyaratan analisis data untuk uji linearitas data, dilakukan untuk memastikan hubungan antara variabel bebas dan variabel terikat bersifat linier. Supardi (2013: 149) menyatakan bahwa uji kelinieran dilakukan untuk menguji: hipotesis: $H_{0}: Y=a+b X$ (linier); dan $H_{1}: Y \neq a+b X$ (tidak linier).
Berdasarkan perhitungan yang sudah dilakukan, berikut ini ringkasan hasil uji normalitas data untuk semua variabel penelitian. Adapun uji lineartitas pada penelitian ini yaitu uji linearitas Kemampuan Komunikasi Matematis dan Prestasi Belajar Matematika, serta uji lenearitas Kemandirian Belajar dan Prestasi Belajar Matematika.

Tabel 3. Tabel Ringkasan Uji Linearitas $X_{1}$ dan $Y$

\begin{tabular}{lccccc}
\hline $\begin{array}{c}\text { Sumber Varian } \\
(\text { SV) }\end{array}$ & $\begin{array}{c}\text { Derajat } \\
\text { Kebebasan (dk) }\end{array}$ & $\begin{array}{c}\text { Jumlah } \\
\text { Kuadrat (JK) }\end{array}$ & $\begin{array}{c}\text { Rata-rata Jumlah } \\
\text { Kuadrat (RJK) }\end{array}$ & $\mathbf{F}_{\text {hitung }}$ & $\mathbf{F}_{\text {tabel }}$ \\
\hline Total & 41 & 66870,00 & - & 0,30 & 2,15 \\
Regresi (a) & 1 & 62283,02 & 62283,02 & Simpulan: & Karena $F_{\text {hitung }}<F_{\text {tabel }}$ atau \\
Regresi (b/a) & 1 & 2211,57 & 2211,57 & $0,30<2,15$, maka dapat \\
Residu & 39 & 2375,40 & 60,91 & disimpulkan bahwa metode \\
Tuna Cocok & 21 & 621,74 & 29,61 & regresi Y terhadap X $X_{1}$ berpola \\
Kesalahan (err) & 18 & 1753,67 & 97,43 & linier. \\
\hline
\end{tabular}

Tabel 4. Tabel Ringkasan Uji Linearitas $X_{2}$ dan $Y$

\begin{tabular}{lccccc}
\hline $\begin{array}{c}\text { Sumber Varian } \\
(\text { SV) }\end{array}$ & $\begin{array}{c}\text { Derajat } \\
\text { Kebebasan (dk) }\end{array}$ & $\begin{array}{c}\text { Jumlah } \\
\text { Kuadrat (JK) }\end{array}$ & $\begin{array}{c}\text { Rata-rata Jumlah } \\
\text { Kuadrat (RJK) }\end{array}$ & $\mathbf{F}_{\text {hitung }}$ & $\mathbf{F}_{\text {tabel }}$ \\
\hline Total & 41 & 66870,00 & - & 0,95 & 2,70 \\
Regresi (a) & 1 & 62283,02 & 62283,02 & Simpulan: & Karena $F_{\text {hitung }}<F_{\text {tabel }}$ atau \\
Regresi (b/a) & 1 & 1435,55 & 1435,55 & $0,95<2,70$, maka dapat \\
Residu & 39 & 3151,43 & 80,81 & disimpulkan bahwa metode \\
Tuna Cocok & 29 & 2309,76 & 79,65 & regresi Y terhadap X $X_{2}$ berpola \\
Kesalahan (Err) & 10 & 841,67 & 84,17 & linear. \\
\hline
\end{tabular}

Pengujian persyaratan analisis data untuk uji multikolinearitas, dimana uji multikolinearitas dilakukan untuk mengetahui hubungan antar variabel bebas yaitu ada atau tidaknya hubungan antara variabel kemampuan komunikasi matematis dengan kemandirian belajar. Kriteria pengujiannya adalah kedua variabel bebas tidak terdapat masalah multikolinearitas jika nilai Variance Inflation Factor (VIF) < 10. Berdasarkan hasil perhitungan uji multikolinearitas, diperoleh bahwa nilai VIF $=1,167<10$, hal ini berarti variabel terbebas dari asumsi klasik multikolinearitas atau dengan kata lain kedua variabel bebas tidak terdapat masalah multikolinearitas. 
Setelah semua uji persyaratan analisis terpenuhi, dilanjutkan dengan pengujian hipotesis, yaitu: (1) uji pengaruh kemampuan komunikasi matematis dan kemandirian belajar secara bersama-sama terhadap prestasi belajar matematika; (2) uji pengaruh kemampuan komunikasi matematis terhadap prestasi belajar matematika; dan (3) uji pengaruh kemandirian belajar terhadap prestasi belajar matematika. Untuk uji hipotesis pertama dilakukan dengan uji $\boldsymbol{F}$, dimana hipotesis yang diuji yaitu: $H_{0}$ : regresi ganda $\mathrm{Y}$ atas $\mathrm{X}_{1}$ dan $\mathrm{X}_{2}$ tidak signifikan, melawan $H_{1}$ : regresi ganda Yatas $\mathrm{X}_{1}$ dan $\mathrm{X}_{2}$ signifikan. Atau secara statistik ditulis: $H_{0}: \beta_{1}=\beta_{2}=0$ melawan $H_{1}: \beta_{1}=\beta_{2} \neq 0$. Setelah dilakukan perhitungan, diperoleh harga $\boldsymbol{F}_{\text {hitung }}>$ $\boldsymbol{F}_{\text {tabel }}$ yaitu 26,67 $>3,25$, maka $H_{0}$ ditolak dan disimpulkan terdapat pengaruh yang signifikan kemampuan komunikasi matematis $\left(\mathrm{X}_{1}\right)$ dan kemandirian belajar $\left(\mathrm{X}_{2}\right)$ secara bersama-sama terhadap prestasi belajar matematika (Y). Adapun persamaan regresi ganda yang terbangun pada penelitian ini adalah $\widehat{\mathbf{Y}}=-4,661+$ $0,824 \mathbf{X}_{\mathbf{1}}+0,371 \mathbf{X}_{\mathbf{2}}$ dan besarnya kontribusi kemampuan komunikasi matematis $\left(\mathrm{X}_{1}\right)$ dan kemandirian belajar $\left(X_{2}\right)$ secara bersama-sama terhadap prestasi belajar matematika (Y) adalah $58,2 \%$

Kemudian untuk uji hipotesis kedua dan ketiga dilakukan dengan uji $\boldsymbol{t}$. Harga $\boldsymbol{t}_{\text {tabel }}$ pada $\propto=0,05$ dan $\mathrm{dk}=\mathrm{n}-\mathrm{k}-1=38 ; \mathrm{k}=$ banyaknya variabel bebas $=2$. Untuk uji dua pihak diperoleh harga $\boldsymbol{t}_{\text {tabel }}=2,02$. Untuk hipotesis kedua, hasil uji $\boldsymbol{t}$ yang sudah dilakukan, diperoleh nilai ternyata $\boldsymbol{t}_{\text {tabel }}>\boldsymbol{t}_{\text {tabel }}$ yaitu 4,98 $>2,02$ maka $\mathrm{H}_{0}$ ditolak, dan disimpulkan terdapat pengaruh yang signifikan kemampuan komunikasi matematis $\left(\mathrm{X}_{1}\right)$ terhadap prestasi belajar matematika. Kemudian besarnya nilai $\boldsymbol{r}=0,69$ dan besarnya kontribusi kemampuan komunikasi matematis $\left(\mathrm{X}_{1}\right)$ terhadap prestasi belajar matematika (Y) adalah 47,6\%. Untuk hipotesis ketiga, hasil uji $\boldsymbol{t}$ yang sudah dilakukan, diperoleh nilai ternyata $\boldsymbol{t}_{\text {tabel }}>\boldsymbol{t}_{\text {tabel }}$ yaitu 3,05 $>2,02$ maka $\mathrm{H}_{0}$ ditolak, disimpulkan disimpulkan terdapat pengaruh yang signifikan kemandirian belajar $\left(\mathrm{X}_{2}\right)$ terhadap prestasi belajar matematika. Kemudian besarnya nilai $\boldsymbol{r}=0,32$ dan besarnya kontribusi kemandirian belajar $\left(\mathrm{X}_{2}\right)$ terhadap prestasi belajar matematika (Y) adalah 10,6\%.

\section{Pembahasan Hasil Penelitian}

1. Pengaruh kemampuan komunikasi matematis $\left(\mathrm{X}_{1}\right)$ dan kemandirian belajar $\left(\mathrm{X}_{2}\right)$ secara bersama-sama terhadap prestasi belajar matematika (Y)

Berdasarkan pada perhitungan data hasil penelitian menunjukkan bahwa terdapat pengaruh yang signifikan kemampuan komunikasi matematis dan kemandirian belajar secara bersama-sama terhadap prestasi belajar matematika. Hasil perhitungan menunjukkan persamaan regresi ganda yang terbangun pada penelitian ini adalah $\widehat{\mathbf{Y}}=-4,661+$ $0,824 \mathbf{X}_{\mathbf{1}}+0,371 \mathbf{X}_{\mathbf{2}}, \quad$ artinya konstanta sebesar $\quad-4,661$ menyatakan bahwa jika tidak ada kemampuan komunikasi matematis dan kemandirian belajar maka prestasi belajar matematika siswa diperoleh sebesar 4,661. Atau dengan kata lain, prestasi belajar matematika siswa diperoleh sebesar 4,661 jika kemampuan komunikasi matematis dan kemandirian belajar diabaikan. Kemudian hasil perhitungan juga menunjukkan besarnya kontribusi kemampuan komunikasi matematis $\left(\mathrm{X}_{1}\right)$ dan 
kemandirian belajar $\left(\mathrm{X}_{2}\right)$ secara bersama-sama terhadap prestasi belajar matematika (Y) adalah $58,2 \%$, artinya untuk $100 \%$ prestasi belajar matematika yang diraih siswa, kemampuan komunikasi matematis dan kemandirian belajar secara bersama-sama memberi kontribusi sebesar 58,2\%, sisanya dipengaruhi oleh faktor lain yang tidak dibahas dalam penelitian ini.

Melalui komunikasi dalam matematika, diharapkan dapat menolong guru memahami kemampuan siswa dalam menginterpretasikan dan mengekspresikan pemahamannya tentang konsep dan proses matematika yang mereka pelajari. Dalam proses pembelajaran matematika, menurut Susanto (2013: 217) mengatakan bahwa "berkomunikasi matematis perlu ditumbuhkan, sebab salah satu fungsi pelajaran matematika yaitu sebagai cara mengkomunikasikan gagasan secara praktis, sistematis, dan efisien". Untuk mengoptimalkan kemampuan komunikasi matematis siswa, sebaiknya menggunakan pembelajaran yang memberikan kesempatan kepada siswa untuk mandiri, serta saling berdiskusi dan berinteraksi dalam pembelajaran, sehingga diharapkan prestasi belajar siswa akan meningkat. Disamping kemampuan komunikasi matematis, kemandirian belajar juga diperlukan agar siswa mempunyai tanggung jawab dalam mengatur dan mendisiplinkan dirinya, serta dalam mengembangkan kemampuan belajarnya atas kemauan sendiri. Haroen (2015: 494) menyatakan bahwa "kemandirian yang terdapat pada diri siswa menjadi faktor utama untuk pencapaian prestasi belajar yang baik". Dengan begitu diharapkan dengan kemandirian yang ada pada diri siswa tersebut memberikan prestasi belajar yang memuaskan.

Sikap mandiri tidak akan dimiliki peserta didik dengan cepat, tetapi membutuhkan kesadaran diri, kebiasaan dan latihan kedisiplinan yang bertahap. Peserta didik akan mandiri dalam belajar apabila peserta didik tersebut sadar akan pentingnya belajar bagi kehidupan di masa sekarang dan di masa yang akan datang. Dalam proses pembelajaran matematika, menurut Susanto (2013: 217) mengatakan bahwa "berkomunikasi matematis perlu ditumbuhkan, sebab salah satu fungsi pelajaran matematika yaitu sebagai cara mengkomunikasikan gagasan secara praktis, sistematis, dan efisien". Melalui komunikasi dalam matematika, diharapkan dapat menolong guru memahami kemampuan siswa dalam menginterpretasikan dan mengekspresikan pemahamannya tentang konsep dan proses matematika yang mereka pelajari. Upaya untuk meningkatkan kemampuan komunikasi matematis siswa tentunya tidak terlepas dari proses pembelajaran. Untuk mengoptimalkan kemampuan komunikasi matematis siswa, sebaiknya menggunakan pembelajaran yang memberikan kesempatan kepada siswa untuk mandiri, serta saling berdiskusi dan berinteraksi dalam pembelajaran, sehingga diharapkan prestasi belajar siswa akan meningkat. Di samping kemampuan komunikasi matematis, kemandirian belajar juga diperlukan agar siswa mempunyai tanggung jawab dalam mengatur dan mendisiplinkan dirinya, serta dalam mengembangkan kemampuan 
belajarnya atas kemauan sendiri. Haroen (2015: 494) menyatakan bahwa "kemandirian yang terdapat pada diri siswa menjadi faktor utama untuk pencapaian prestasi belajar yang baik". Dengan begitu diharapkan dengan kemandirian yang ada pada diri siswa tersebut memberikan prestasi belajar yang memuaskan.

2. Pengaruh kemampuan komunikasi matematis $\left(\mathrm{X}_{1}\right)$ terhadap prestasi belajar matematika (Y)

Berdasarkan pada perhitungan data hasil penelitian menunjukkan bahwa terdapat pengaruh yang signifikan kemampuan komunikasi matematis terhadap prestasi belajar matematika. Hasil perhitungan menunjukkan nilai $\boldsymbol{t}_{\text {tabel }}>\boldsymbol{t}_{\text {tabel }}$ yaitu $3,05>2,02$. Kemudian besarnya nilai $\boldsymbol{r}=0,32$ dan besarnya kontribusi kemampuan komunikasi matematis $\left(\mathrm{X}_{1}\right)$ terhadap prestasi belajar matematika (Y) adalah $10,6 \%$. Seperti yang sudah diketahui, besarnya kontribusi kemampuan komunikasi matematis $\left(\mathrm{X}_{1}\right)$ dan kemandirian belajar $\left(\mathrm{X}_{2}\right)$ secara bersama-sama terhadap prestasi belajar matematika (Y) adalah $58,2 \%$, artinya untuk $100 \%$ prestasi belajar matematika yang diraih siswa, kemampuan komunikasi matematis dan kemandirian belajar secara bersama-sama memberi kontribusi sebesar 58,2\%, sisanya dipengaruhi oleh faktor lain yang tidak dibahas dalam penelitian ini. Diketahui dari kontribusi bersamasama sebesar 58,2\% ini, kontribusi kemampuan komunikasi matematis $\left(\mathrm{X}_{1}\right)$ terhadap prestasi belajar matematika (Y) adalah 10,6\%. Kemampuan komunikasi berperan atau memberi sumbangsih atas prestasi belajar matematika.
Berdasarkan pada perhitungan data hasil penelitian menunjukkan bahwa terdapat pengaruh yang signifikan kemampuan komunikasi matematis terhadap prestasi belajar matematika. Hasil penelitian ini sejalan dengan penelitian yang dilakukan oleh Astuti dan Leonard (2012: 109) menyatakan bahwa "prestasi belajar siswa akan semakin baik jika kemampuan komunikasi matematika ditingkatkan". Dalam hal ini, kemampuan komunikasi matematis memegang peranan yang penting dalam terjadinya proses belajar mengajar bagi siswa.

Kemampuan komunikasi matematis merupakan salah satu kemampuan dasar yang harus dimiliki siswa dan guru dalam KBM, terutama dalam pembelajaran matematika. Hal ini senada dengan pendapat Mahmudi (2009: 1) dalam jurnalnya yang memaparkan bahwa "komunikasi harus menjadi salah satu aspek yang dikembangkan dalam pembelajaran matematika". Kemampuan komunikasi matematis yang baik, akan menciptakan atau melahirkan suasana lingkungan belajar yang nyaman, sehingga hubungan antara siswa dengan guru menjadi lebih dekat, serta dapat mendorong siswa menjadi aktif.

Oleh karena itu, untuk meningkatkan prestasi belajar siswa, guru perlu memperhatikan faktorfaktor yang mempengaruhi prestasi belajar siswa, baik faktor internal maupun faktor eksternal. Kemampuan komunikasi matematis yang baik, akan menciptakan atau melahirkan suasana lingkungan belajar yang nyaman, sehingga hubungan antara siswa dengan guru menjadi lebih dekat, serta dapat mendorong siswa menjadi aktif dalam kegiatan belajar mengajar. 
3. Pengaruh kemandirian belajar $\left(\mathrm{X}_{2}\right)$ terhadap prestasi belajar matematika (Y)

Berdasarkan pada perhitungan data hasil penelitian menunjukkan bahwa terdapat pengaruh yang signifikan kemandirian belajar terhadap prestasi belajar matematika. Hasil perhitungan menunjukkan nilai $\boldsymbol{t}_{\text {tabel }}>\boldsymbol{t}_{\text {tabel }}$ yaitu $4,98>2,02$. Kemudian besarnya nilai $\boldsymbol{r}=0,69$ dan besarnya kontribusi kemandirian belajar $\left(\mathrm{X}_{2}\right)$ terhadap prestasi belajar matematika (Y) adalah 47,6\%. Seperti yang sudah diketahui, besarnya kontribusi kemampuan komunikasi matematis $\left(\mathrm{X}_{1}\right)$ dan kemandirian belajar $\left(\mathrm{X}_{2}\right)$ secara bersama-sama terhadap prestasi belajar matematika (Y) adalah $58,2 \%$, artinya untuk $100 \%$ prestasi belajar matematika yang diraih siswa, kemampuan komunikasi matematis dan kemandirian belajar secara bersama-sama memberi kontribusi sebesar 58,2\%, sisanya dipengaruhi oleh faktor lain yang tidak dibahas dalam penelitian ini. Diketahui dari kontribusi bersamasama sebesar 58,2\% ini, kontribusi kemandirian belajar $\left(\mathrm{X}_{2}\right)$ terhadap prestasi belajar matematika (Y) adalah 47,6\%. Dengan demikian, kemandirian belajar berperan atau memberi sumbangsih atas prestasi belajar matematika.

Berdasarkan pada perhitungan data hasil penelitian menunjukkan bahwa terdapat pengaruh yang signifikan kemandirian belajar terhadap prestasi belajar matematika. Hal ini sesuai dengan penelitian Lisa Sri Devi (2014) yang menyimpulkan bahwa "terdapat pengaruh yang positif antara kemandirian belajar terhadap prestasi belajar matematika siswa". Kemandirian belajar siswa dapat dilihat pada kesiapan siswa dalam menerima pelajaran. Siswa yang memiliki kemandirian belajar akan mampu mencari sumber belajar yang dibutuhkan, serta mempunyai inisiatif sendiri dan mampu bekerja sendiri.

Kemandirian merupakan sesuatu yang penting dalam belajar. Haroen (2015: 494) menyatakan bahwa "kemandirian yang terdapat pada diri siswa menjadi faktor utama untuk pencapaian prestasi belajar yang baik". Artinya, peserta didik perlu memiliki kesadaran, kemauan, dan motivasi dari dalam diri peserta didik untuk berbuat, bertindak, dan berpikir atas dasar kreatif dan penuh inisiatif, percaya diri, bertanggung jawab, dan bukan semata-mata tekanan dari guru atau pihak lain.

Hal ini sesuai dengan yang dikemukakan Nursobah (2009: 2) yaitu, "salah satu hal yang dapat mempengaruhi prestasi belajar siswa adalah kemandirian siswa dalam belajar". Dengan adanya kemandirian dari dalam diri siswa, maka akan ada dorongan bagi siswa untuk belajar lebih efektif agar tercapai tujuan dalam pembelajaran. Dengan memaksimalkan kemandirian belajar, akan memacu prestasi belajar siswa khususnya dalam pelajaran matematika.

Kemandirian belajar siswa dapat dilihat pada kesiapan siswa dalam menerima pelajaran. Siswa yang memiliki kemandirian belajar akan mampu mencari sumber belajar yang dibutuhkan, serta mempunyai inisiatif sendiri dan mampu bekerja sendiri. Dengan adanya kemandirian dari dalam diri siswa maka akan ada dorongan bagi siswa untuk belajar lebih efektif agar tercapai tujuan dalam pembelajaran. Hal ini sesuai dengan yang dikemukakan Nursobah (2009: 2) yaitu, "salah satu hal yang 
dapat mempengaruhi prestasi belajar siswa adalah kemandirian siswa dalam belajar". Dengan memaksimalkan kemandirian belajar, akan memacu prestasi belajar siswa khususnya dalam pelajaran matematika. Aktivitas belajar yang sesuai dengan tahapan-tahapan yang teratur akan mencapai tujuan belajar yang maksimal dan prestasi belajar akan meningkat secara otomatis. Berdasarkan uraian di atas, dapat disimpulkan bahwasanya terdapat pengaruh antara kemandirian belajar terhadap prestasi belajar matematika.

\section{SIMPULAN DAN SARAN}

\section{Simpulan}

Berdasarkan deskripsi hasil penelitian dan juga berdasar pada hasil analisis data serta pengujian hipotesis dalam penelitian ini, dapat disimpulkan sebagai berikut: (1) Terdapat pengaruh yang signifikan kemampuan komunikasi matematis dan kemandirian belajar secara bersama-sama terhadap prestasi belajar matematika siswa di MTs Daarussalaam, Jakarta Selatan. Hal ini dibuktikan dengan nilai $\boldsymbol{F}_{\text {hitung }}>$ $\boldsymbol{F}_{\text {tabel }}$ yaitu 26,67 > 3,25; (2) Terdapat pengaruh yang signifikan kemampuan komunikasi matematis terhadap prestasi belajar matematika siswa di MTs Daarussalaam, Jakarta Selatan. Hal ini dibuktikan dengan nilai $\boldsymbol{t}_{\text {hitung }}>\boldsymbol{t}_{\text {tabel }}$ yaitu $4,98>2,02$. (3) Terdapat pengaruh yang signifikan kemandirian belajar terhadap prestasi belajar matematika siswa di MTs Daarussalaam, Jakarta Selatan. Hal ini dibuktikan dengan nilai $\boldsymbol{t}_{\text {hitung }}>\boldsymbol{t}_{\text {tabel }}$ yaitu $3,05>2,02$.

\section{Saran}

Berdasarkan penelitian yang sudah dilaksanakan, peneliti berharap sistem pendidikan di Indonesia dapat berkembang menjadi lebih baik. Peneliti juga meminta bantuan dari pihak sekolah dan guru agar hasil penelitian ini dapat digunakan sebaik mungkin dalam upaya meningkatkan prestasi belajar matematika siswa, baik di sekolah maupun di luar sekolah. Adapun saran peneliti diantaranya dengan terbukti pengaruh mengenai kemampuan komunikasi matematis dan kemandirian belajar terhadap prestasi belajar matematika maka untuk pihak sekolah perlu diupayakan suatu sistem yang dapat meningkatkan prestasi belajar matematika khususnya dan juga untuk pelajaran lainnya; Untuk meningkatkan prestasi belajar matematika, seorang siswa perlu merencanakan strategi belajar, memiliki kemandirian, serta aktif di dalam kelas. Sehingga, dengan merencanakan strategi belajar, menjalankan proses belajar dengan baik, dan komunikasi terjalin dengan baik, maka tujuan belajar akan dapat dicapai; Perlu penelitian lebih lanjut yang memasukkan variabel selain kemampuan komunikasi matematis dan kemandirian belajar sebagai prediktor yang lebih lengkap bagi peningkatan prestasi belajar matematika. Demikian saran yang dapat peneliti sampaikan, meskipun apa yang disarankan jauh dari kesempurnaan, namun diharapkan hasil penelitian ini dapat memberikan gambaran yang representatif untuk menunjang kegiatan belajar siswa agar tercapai hasil yang lebih maksimal terutama pada bidang studi matematika. 


\section{DAFTAR RUJUKAN}

Depdiknas. 2003. Undang-Undang Nomor 20 Tahun 2003 Tentang Sistem Pendidikan Nasional dan Penjelasannya. Yogyakarta: Media Wacana.

2005. Pedoman Umum Ejaan Bahasa Indonesia yang Disempurnakan. Jakarta: Balai Pustaka.

----- 2008. Kamus Besar Bahasa Indonesia Pusat Bahasa Edisi Keempat. Jakarta: Gramedia Pustaka Utama.

Devi, L. S. 2014. Pengaruh Kemandirian Belajar terhadap Prestasi Belajar Matematika Siswa (Survei pada siswa kelas VIII di SMP Al-Muslim Tambun Selatan Bekasi). Jakarta: FTMIPA Universitas Indraprasta PGRI.

Haroen, Z. A. 2015. Pengaruh Kemandirian Siswa terhadap Prestasi Belajar Matematika. Prosiding Seminar Nasional Pendidikan Matematika ISBN. 978-6021108-46-8. Universitas Indraprasta PGRI.

Jazuli, A. 2009. Berpikir Kreatif dalam Kemampuan Komunikasi Matematika. http://eprints.uny.ac.id/7025/1/P11-Akhmad\%20Jazuli.pdf. Diakses 20 Desember 2015.

Leonard. 2013. Kajian Peran Konsistensi Diri terhadap Prestasi Belajar Matematika. Jurnal Formatif. Vol. 3(2): 97-104. Universitas Indraprasta PGRI.

Nursobah, A. 2009. Hubungan Antara Kemandirian Belajar, Komunikasi Interpersonal dan Identitas Sosial dengan Hasil Belajar Agama Islam. Jurnal. Bandung: UIN Sunan Gunung Djati.

Ramdhana, Y. 2012. Pengembangan Instrumen dan Bahan Ajar untuk Meningkatkan Kemampuan Komunikasi, Penalaran, dan Koneksi Matematis dalam Konsep Integral". http://jurnal.upi.edu/file/6-yani_ramdhana-edi.pdf. Diakses 20 Desember 2015.

Sugandi, A. I. 2013. Pengaruh Pembelajaran Berbasis Masalah dengan Setting Kooperatif Jigsaw terhadap Kemandirian Belajar Siswa SMA. http://ejournal.stkipsiliwangi.ac.id/index.php/infinity/article/view/31. Diakses pada 20 Desember 2015.

Supardi. 2013. Aplikasi Statistika dalam Penelitian: Konsep Statistika yang Lebih Komprehensif. Jakarta: Ufuk Publishing House.

Susanto, A. 2013. Teori Belajar dan Pembelajaran di Sekolah Dasar. Jakarta: Kencana Prenadamedia Group.

Wahyuningrum, E. 2013. Pengembangan Kemampuan Komunikasi Matematik Siswa SMP Pengembangan Kemampuan Komunikasi Matematik dengan MEAs (Developing Mathematical Communication Skills for Junior High School Students). Jurnal Pendidikan, Vol. 14 (1), Maret 2013, 1-10.

West, R dan Lynn H. T. (2008). Pengantar Teori Komunikasi: Analisis dan Aplikasi (Buku 2) (Edisi 3). Jakarta: Salemba Humanika. 